\title{
Negative reciprocity and retrenched pension rights
}

Citation for published version (APA):

Montizaan, R. M., Cörvers, F., de Grip, A., \& Dohmen, T. J. (2012). Negative reciprocity and retrenched pension rights. METEOR, Maastricht University School of Business and Economics. METEOR Research Memorandum No. 052 https://doi.org/10.26481/umamet.2012052

Document status and date:

Published: 01/01/2012

DOI:

10.26481/umamet.2012052

Document Version:

Publisher's PDF, also known as Version of record

\section{Please check the document version of this publication:}

- A submitted manuscript is the version of the article upon submission and before peer-review. There can be important differences between the submitted version and the official published version of record.

People interested in the research are advised to contact the author for the final version of the publication, or visit the DOI to the publisher's website.

- The final author version and the galley proof are versions of the publication after peer review.

- The final published version features the final layout of the paper including the volume, issue and page numbers.

Link to publication

\footnotetext{
General rights rights.

- You may freely distribute the URL identifying the publication in the public portal. please follow below link for the End User Agreement:

www.umlib.nl/taverne-license

Take down policy

If you believe that this document breaches copyright please contact us at:

repository@maastrichtuniversity.nl

providing details and we will investigate your claim.
}

Copyright and moral rights for the publications made accessible in the public portal are retained by the authors and/or other copyright owners and it is a condition of accessing publications that users recognise and abide by the legal requirements associated with these

- Users may download and print one copy of any publication from the public portal for the purpose of private study or research.

- You may not further distribute the material or use it for any profit-making activity or commercial gain

If the publication is distributed under the terms of Article $25 \mathrm{fa}$ of the Dutch Copyright Act, indicated by the "Taverne" license above, 


\section{Maastricht University}

Raymond Montizaan, Frank Cörvers, Andries de Grip, Thomas Dohmen

Negative Reciprocity and retrenched pension rights

$\mathrm{RM} / 12 / 052$

\section{METEOR}

Maastricht University School of Business and Economics

Maastricht Research School of Economics

of Technology and Organization

PO. Box 616

NL - 6200 MD Maastricht

The Netherlands 


\title{
Negative Reciprocity and retrenched pension rights*
}

\author{
Raymond Montizaan, Frank Cörvers, Andries De Grip, Thomas Dohmen
}

October, 2012

\begin{abstract}
We document the importance of negatively reciprocal inclinations in labor relationships by showing that a retrenchment of pension rights, which is perceived as unfair, causes a larger reduction in job motivation the stronger workers' negatively reciprocal inclinations are. We exploit unique matched survey and administrative data on male employees in the public sector in the Netherlands and compare the job motivation of employees born in 1950, who faced a substantial retrenchment of their pension rights resulting from a pension reform in 2006, to that of slightly older employees who remain entitled to more generous pension benefits. Job motivation is significantly lower among negatively reciprocal employees who were affected by the reform. The negative effect on job motivation is greater for negative reciprocal employees born very shortly after the cut-off date of January 1, 1950, as well as for those with many untreated colleagues, and who therefore arguably perceive the policy change as being more unfair. We also find that the treatment effect is stronger among workers who are more likely to hold their employer accountable for the drop in their pension rights, that is, those who work for the national government.
\end{abstract}

Keywords: reciprocity, job motivation, retrenchment of pension rights.

JEL codes: D63, J2.

*Montizaan: Maastricht University, Research Centre for Education and the Labour Market (ROA), School of Business and Economics, P.O. Box 616, 6200 MD Maastricht, The Netherlands (e-mail: r.montizaan@maastrichtuniversity.nl); Cörvers: Maastricht University, Research Centre for Education and the Labour Market (ROA), School of Business and Economics, P.O. Box 616, 6200 MD Maastricht, The Netherlands (e-mail: frank.corvers@maastrichtuniversity.nl); De Grip: Maastricht University, Research Centre for Education and the Labour Market (ROA), School of Business and Economics, P.O. Box 616, 6200 MD Maastricht, The Netherlands (e-mail: a.degrip@maastrichtuniversity.nl); Dohmen: Maastricht University, Research Centre for Education and the Labour Market (ROA), School of Business and Economics, P.O. Box 616, 6200 MD Maastricht, The Netherlands (e-mail: t.dohmen@maastrichtuniversity.nl). 


\section{Introduction}

Experimental economists and psychologists have provided ample evidence from controlled laboratory studies that reciprocity is a key driver of human motivation (Bowles, 2008). ${ }^{1}$ Theory predicts that reciprocity also affects labor market outcomes (e.g., Akerlof, 1982; Rabin, 1993). Important implications are, for example, that positively reciprocal employees increase their efforts above the required level when treated generously by their employers and that negatively reciprocal workers retaliate against their employers for unfair treatment, for example, by reducing effort.

Previous empirical work on the role of reciprocity in employment relationships focused largely on the impact of positive reciprocity on workers' effort response in gift exchanges. Convincing evidence of in-kind response by workers (i.e., higher effort provision) to the friendly actions of employers (i.e., a higher wage payment) has been found in stylized labor markets in laboratory experiments (e.g., Fehr et al., 1993; Fehr et al., 1998; Brown et al., 2004). ${ }^{2}$ Evidence from field experiments is somewhat less conclusive. Despite the overwhelming evidence of reference-dependent fairness concerns (e.g. Fehr et al., 1993; Fehr et al., 2009), researchers still debate on the extent to which employers' generous treatment of workers cause increased effort provision. ${ }^{3}$ Some complementary correlational evidence for the relevance of gift exchange in actual labor markets has been provided

\footnotetext{
${ }^{1}$ Numerous studies have shown that individuals reciprocate trust in trust games (Berg et al., 1995). Moreover, it has been documented that individuals (in bargaining games) are willing to reject unfair offers, even at personal cost (e.g., Güth et al., 1982; Camerer and Thaler, 1995), and those who participate in public good games are prepared to punish deviations from average or individual contributions (e.g. Fehr and Gächter, 2000)

${ }^{2}$ Several field experiments in non-labor market contexts (e.g.; Falk, 2007; Falk and Zehnder, 2007) have recently shown that reciprocal motives have a significant impact on human behavior outside stylized laboratory environments.

${ }^{3}$ Gneezy and List (2006) found that an unexpected salary raise has only a short-lived positive effect on work effort in a gift exchange game. Kube et al. (2012b) found that wage cuts have a detrimental and persistent impact on productivity, while an equivalent wage increase has no effect. Cohn et al. (2009) conducted a field experiment in which wages are increased and found that workers who felt underpaid at the baseline wage react to the wage increase strongly by raising effort, while workers who felt paid fairly at the baseline wage do not increase their effort. Bellemare and Shearer (2009) found that providing a bonus unrelated to past productivity in a field experiment at a tree-planting firm has a significant and positive effect on productivity. Finally, in contrast to these experiments, where the generous worker treatment is only in terms of higher wages or bonuses, Kube et al. (2012a) demonstrate that non-monetary gifts have a much stronger impact on worker effort provision than monetary gifts.
} 
by Dohmen et al. (2009). They analyzed survey data and showed that measures of positively reciprocal dispositions of respondents in the German Socio-Economic Panel Study (SOEP) are significantly correlated with higher wages and greater work effort.

Few studies have focused on the impact of perceived unfair treatment on worker motivation and effort provision. An important exception is the interesting case study by Krueger and Mas (2004) who document that labor strife at a U.S. tire production site coincided with the production of substantially lower-quality tires, which arguably resulted from the reduced effort and care of workers during the strife. This indicates that harmful reciprocations are important in actual labor market settings.

This study uses a regression discontinuity design (Imbens and Lemieux, 2008; Lee and Lemieux, 2010) to analyze the impact on job motivation of a legislative change that curtailed the pensions of Dutch public sector employees born in 1950 and later, but did not change those of public sector employees born in 1949 and earlier. Until 2006, contributions to sectoral early retirement schemes in the Netherlands were tax deductible, which substantially boosted their financial attractiveness. The legislative change consisted of the abolishment of this favorable tax treatment. The abolition was not limited to the public sector and also applied to workers in the private sector; however, the major difference between the sectors is that in the public sector the national government is both the initiator of the pension reform and the employer in the sectoral bargaining process. For the public sector we can therefore exploit the specific situation that, since the government initiated the policy change, public sector employees born in 1950 are likely to perceive their employer as directly responsible for the deterioration of their pensions.

The retrenchment of the pension rights of public sector employees constitutes a breach of an informal agreement because the prospect of early retirement with high pension benefits was emphasized as an attractive job characteristic in the recruitment of public sector workers since the second half of the 1970s. One could conjecture that such a breach of an implicit contract triggers retaliation for deterrence in the employer-employee relationship. We would therefore expect that the treated employees (i.e., those born just 
after December 31, 1949) are, on average, less motivated in their job than workers in our control group, who are slightly older (i.e., born just before January 1, 1950) but otherwise similar. Such a finding would be important by itself, since it would corroborate the findings of Krueger and Mas (2004).

Besides facing the breach of an informal contract, workers born in 1950 who compare their pension rights to their own status quo before the policy change and to those who still enjoy the older, more generous pension plan are likely to perceive the policy change as unfair. If social motives drive negative reciprocity, we should expect that the negatively reciprocal inclinations of workers catalyze the decline in job motivation after being treated unfairly. We therefore hypothesize that worker reactions to 'unfair' treatment are heterogeneous and depend on their negative reciprocal inclinations: Among the treated workers, those with strongly negatively reciprocal inclinations are expected to show a stronger reaction to the unfair treatment than their treated colleagues who have only weak negatively reciprocal inclinations.

We test our hypothesis using unique matched survey and administrative pension fund data on male employees in the Dutch public sector who were born in either 1949 or $1950 .{ }^{4}$ The survey includes six questions validated in a controlled laboratory study by Perugini et al. (2003) as measuring positive and negative reciprocity. ${ }^{5}$ We then compare employee job motivation, a key determinant of work effort, in the treatment group, affected by the retrenchment of pension rights (i.e., those born in 1950), with that in the control group (i.e., those born in 1949) and assess whether the treatment effect depends on their degree of negative reciprocity. ${ }^{6}$

\footnotetext{
${ }^{4}$ These data were also used by De Grip et al. (2012) who found a strong negative effect on the mental health of treated workers, and by Montizaan and Vendrik (2012), who study the impact of a reduction in pension wealth on life satisfaction and job satisfaction. Neither study considered heterogeneous effects that depend on negatively reciprocal motivations.

${ }^{5}$ Perugini et al. (2003) performed comprehensive validation tests for their reciprocity scale and showed that the measure for negative reciprocity predicts behavior in ultimatum games.

${ }^{6}$ Brown and Leigh (1996) investigated the process by which employee perceptions of a motivating work environment are related to job involvement, effort and performance and found that a motivating environment is related to job involvement, which in turn is strongly related to effort provision. Judge et al. (2001) performed two meta-analyses on the relation between job satisfaction and job performance and found a strong correlation between these two variables. Duncan et al. (1998) examined the relationship between motivation and labor-market success using a sample from the Panel Study of Income Dynamics
} 
In our study, we show that workers with negatively reciprocal inclinations become less motivated when they are in treated in a negative way. This results indicates that the harmful effects of unfair treatment that previous studies have documented (e.g., Krueger and Mas, 2004) are indeed driven by negatively reciprocal inclinations. More specifically, we find that the exogenous decrease in pension benefits is associated with a significant reduction in job motivation among negatively reciprocal employees. Job motivation is lowest for treated individuals in the top quartile of the distribution of negative reciprocity. Additional evidence strongly supports the idea that the causality runs from unfair treatment to reduced job motivation, which is mediated by the perception of the degree of unfairness and the strength of negatively reciprocal motives. For example, negatively reciprocal treated workers who were closer born to the cut-off date (e.g., born in the first quarter of 1950) or who work in an organization with relatively many untreated colleagues are the least motivated after the reform, indicating that they perceive the policy change as particular unfair. Moreover, job motivation is lower among negatively reciprocal public sector employees who work at central government institutions, most likely because they hold their employer, the government that implemented the policy change, directly accountable for the retrenchment of their pension rights.

Our findings complement the literature in important ways. First, we exploit exogenous variation in unfair worker treatment to shed light on the nature of the relationship between unfair worker treatment and undesired worker response. Second, we use a direct measure of reciprocal inclination to test whether the response of workers is brought about by negative reciprocal motives, and we provide evidence for a causal link between negatively reciprocal inclinations and reductions in job motivation. Finally, we show that heterogeneity in negatively reciprocal inclinations leads to heterogeneity in the effort response of workers who feel treated unfairly. These findings are fundamental, since they indicate that reciprocity is strongly driven by social motives.

(PSID) and found that motivational variables are strongly correlated with future earnings and human capital investments (see also Bowles et al. (2001) for a discussion on the relevancy of motivational traits for pay). 
The remainder of the paper is organized as follows. The next section provides more details on the exogenous shock in the Dutch public sectors' pension system that generates exogenous variation in the way workers are treated. Section 3 describes the data. Section 4 presents the results and Section 5 ends with some concluding remarks.

\section{Reform of the Public Sector's Pension System}

Before discussing important details of the Dutch pension reform, we briefly provide some key features of the Dutch pension system. The Dutch pension system consists of three pillars: 1) a public old age pension that is paid to all inhabitants aged 65 and older, 2) a supplementary sectoral (or firm) pension, and 3) voluntary private pension plans. The public old age pension is essentially a pay-as-you-go system in which current payments are financed by income taxes. Supplementary sectoral (or firm) pensions are of the defined benefit type and very wide spread, since participation in these schemes is generally mandatory. ${ }^{7}$ Additional voluntary pension plans are offered by private insurance companies. These pension plans typically take the form of savings plans that yield annuity payments at retirement age and are less prevalent in the Netherlands.

Early retirement before the age of 65 is primarily made possible through the sectoral pension system (i.e., the second pillar). Until 2006, contributions to the sectoral early retirement schemes were tax deductible, which substantially boosted their financial attractiveness. This tax advantage amounted to about $25 \%$ of the net early retirement allowance (Kooiman et al., 2004), which is partly a result of the progressive tax system (Euwals et al., 2006). Typically, contributions to the sectoral pension schemes were such that a public sector employee who had served for 40 years in the public sector could retire at the age of 62 and three months at a replacement rate of $70 \%{ }^{8}$ As a result, early

\footnotetext{
${ }^{7}$ Most sectoral pension schemes are negotiated between unions and employer organizations at the sector or firm level and are officially laid down in collective agreements. In the public sector, both employers and employees contribute to the pension fund.

${ }^{8}$ Until 2006, workers traditionally retired in the Netherlands when they achieved a replacement rate of $70 \%$.
} 
retirement became the social norm in the Netherlands. Approximately $80 \%$ of all workers retired at the age of 62 or younger before 2006, and only $6 \%$ retired at the age of $65 .^{9}$

In 2006, a reform in the Dutch pension system abolished the favorable tax deductibility of the contributions to the sectoral early retirement schemes for all employees born in 1950 or later, but not for older cohorts. The government's intention was to provide stronger incentives for younger cohorts to retire at an older age. Those born in 1950 and thereafter suffered from a dramatic loss of early retirement options. Employees born before 1950 who had been continuously employed in the public sector since April 1, 1997, remained entitled to the generous old pension rights. The abolition of this favorable tax treatment was not limited to the public sector and also applied to workers in the private sector; however, the major difference between the sectors is that in the public sector the national government is both the initiator of the pension reform and the employer in the sectoral bargaining process. This implies that public sector employees may hold their own employer accountable for the drop in their pension rights.

In response to the abolishment of the favorable tax treatment of early retirement schemes, the social partners in the public sector negotiated a new pension scheme that became effective on January 1, 2006, for workers born in 1950 or later and those who had not worked continuously in the public sector since April 1, 1997. This new scheme is called 'ABP Flexible Pension Scheme' and is carried out by the public sector's pension fund Algemeen Burgelijk Pensioenfonds (ABP). ${ }^{10}$ The new flexible pension system is characterized by i) a drop in pension benefits, ii) an increase in pension contribution payments to partly account for the drop in pension wealth resulting from i), and iii) stronger incentives to continue working, generated by larger penalties on pension income when retiring before commencement of the state pension at age 65 and by larger supplements for later retirement. ${ }^{11}$ As a result, a typical employee born in 1950 or later with

\footnotetext{
${ }^{9}$ See Statistics Netherlands (2009).

${ }^{10}$ Note that the details of the pension scheme have been negotiated by the government and unions, and that $\mathrm{ABP}$ only acts as a subcontractor.

${ }^{11}$ Furthermore, the eligibility age for pension benefits was increased to 60 year, and workers can now decide to continue working until their 70th birthday.
} 
40 years of tenure now only attains a replacement rate of $64 \%$ when retiring early at the age of 62 years and three months, which is substantially lower than the replacement rate of $70 \%$ that applied to them before the reform and still applies to workers born before 1950. To attain a replacement rate of $70 \%$, workers who are affected by the reform have to postpone retirement by one year and three months.

The ABP launched a campaign in the second half of 2005 to inform its members about the introduction of the new pension system and to explain its financial implications. A special newsletter was devoted to the new pension system in which unions, employer organizations, and the ABP jointly explained the new flexible pension scheme. All 1.2 million ABP participants received a letter about the core characteristics of the new scheme, and a complete electronic service package for public service employers was developed. Therefore, one can assume that on January 1, 2006, most public sector employees born after 1949 and their employers were indeed familiar with the exogenous shock in their pension rights. $^{12}$

The strong differential treatment of workers born around January 1, 1950, came as a surprise to public sector employees. Details of the new pension system were only communicated in the second half of 2005 , so that there was not much scope for workers born on January 1, 1950, or later to fully offset the drop in their pension benefits - that is, by engaging in extra savings plans - because of the limited time horizon to retirement. ${ }^{13}$

\footnotetext{
${ }^{12} \mathrm{~A}$ comparison of expectations of the level of pension benefits across the treatment and control groups in the next section of this paper shows that respondents who are affected by the pension reform indeed expect a significantly lower replacement rate, and that the mean expected replacement rates are close to the actual replacement rates of both groups.

${ }^{13}$ However, along with the abolishment of the favorable tax treatment, the government introduced the Life Course Savings program in 2006. This program allows workers born in 1950 to build up tax-free savings of approximately $14 \%$ of their annual earnings for seven years to finance early retirement at age 62 and three months. It is likely that only a very small fraction of these workers are able to save such a high proportion of their earnings each year before retirement.
} 


\section{Data}

\subsection{Data collection}

We use survey data that we match to administrative data for male employees in the public sector who were born in 1949 or $1950 .{ }^{14}$ The administrative data are from the ABP. The data contain detailed information on individuals' pension rights at the ABP, annual wage income, and tenure in the public sector.

The survey data were gathered after the introduction of the new pension system. In January 2007, all 27,871 male public sector employees born in either 1949 or 1950 were invited to participate in our Internet survey by requesting their e-mail addresses. The invitation letter, sent by surface mail, conveyed general information about the social usefulness of the study but did neither reveal any information about the (motivation for the) research question or the nature of our research strategy (e.g., we did not inform potential participants that the invitation was only sent to public sector employees born in 1949 and 1950.) The letter also explicitly assures confidentiality, so that respondents need not fear repercussions from responding in a socially undesired manner. In March 2007, we invited the 11,458 male public sector employees who had provided their contact details to fill in the web-based survey. In total, 7,739 individuals completed the questionnaire in 2007. References to the nature of our research question and research strategy were avoided in the survey itself. In March 2008, we sent an e-mail invitation with a link to a second web-based survey to all individuals who had logged on to the 2007 questionnaire. This time 6,078 respondents completed the survey. In this second wave, we asked detailed questions on reciprocal motivation, job motivation, and retirement expectations.

In our analyses, we exclude workers employed in certain burdensome occupations (e.g., firemen and ambulance and police personnel), in which other retirement schemes are in

\footnotetext{
${ }^{14}$ The survey and administrative data are only available for these two specific birth years. We focus on male employees because only a small, selective group of employees in these birth cohorts in the Netherlands is female.
} 
place that allow early retirement without a substantial drop in income. In our main analysis, we also restrict the sample to those employees who continuously worked in the public sector since 1997 (thereby excluding 260 employees who are not eligible for the pre-reform early retirement option even if they were born before 1950). ${ }^{15}$ Due to item non-response for the variables of interest, the estimation sample is further reduced to 4,520 men, 2,373 of whom were born in 1950 and constitute the treatment group, while the other 2,147 men, born in 1949, belong to the control group.

The dependent variable in our econometric analysis is a self-assessed measure of job motivation. Respondents were asked to indicate how well the following statement applies to them personally: 'At times, I have difficulties motivating myself in my job.' Answer categories ranged from 1 ('applies perfectly to me') to 5 ('does not apply to me at all').

Our measure of reciprocity, one of the key explanatory variables in our analysis, is based on the reciprocity scale developed and validated by Perugini et al. (2003). These authors performed comprehensive validation tests and assessed the predictive power of their reciprocity scale for the behavior of participants in ultimatum games in laboratory experiments conducted in the United Kingdom and Italy. We include the six items that have the highest loadings on the principal components for positive and negative reciprocity and that were also included in the 2005 SOEP wave (see Dohmen et al., 2009) for the behavioral validity of these questions). Respondents had to indicate on a fivepoint Likert scale ( 1 means 'does not apply to me at all' and 5 means 'applies perfectly to me') how well they identified themselves with each of the following six statements: 1) 'If someone does me a favor, I am prepared to return it'; 2) 'If I suffer a serious wrong, I will take revenge as soon as possible, no matter what the costs'; 3) 'If somebody puts me in a difficult position, I will do the same to him/her'; 4) 'I go out of my way to help somebody who has been kind to me before'; 5) 'If somebody offends me, I will offend him/her back'; 6) 'I am ready to undergo personal costs to help somebody who helped

\footnotetext{
${ }^{15}$ In a robustness analysis we include the workers who did not work continuously in the public sector since 1997.
} 
me before'. Statements 2), 3) and 5) refer to negative reciprocity; statements 1), 4) and 6) concern positive reciprocity. We construct our measures of positive and negative reciprocity by taking the arithmetic average of a respondent's answers to questions 2), $3), 5)$ and 1), 4), 6), respectively. ${ }^{16}$

A relevant concern is how well these survey questions measure the behavioral reciprocal inclinations of the individuals in our sample. Various factors such as strategic motives, self-serving biases, and lack of attention can induce respondents to distort or unintentionally miss report their true reciprocal behavior (Camerer and Hogarth, 1999). We are confident, however, that our measures are valid indicators of reciprocity, albeit measured with error, for the following reasons. First, our reciprocity measures are experimentally validated. Second, Dohmen et al. (2009) showed that the survey measures of reciprocity employed in this study are correlated with behavioral outcomes in a way that is consistent with theoretical predictions. Third, previous research demonstrated the validity of survey questions about preferences, attitudes, and behavior (e.g., Fehr et al., 2003; Bellemare and Kröger, 2007; Falk and Zehnder, 2007; Dohmen et al., 2011).

\subsection{Descriptives}

Table 1 presents descriptive statistics for the estimation sample (Column 1), and separately for the control group (Column 2) and treatment group (Column 3). Column 4 shows the p-values for the tests of the hypothesis that the treatment and control group are the same. We do not observe significant differences in the average responses to each of the six different reciprocity measures between the treatment and control groups, indicating that the change in pension rights did not affect self assessed reciprocal inclinations. The sample averages for the three items that measure negative reciprocity range from 2.6 to 3.1 and are smaller than the averages for the items measuring positive reciprocity

\footnotetext{
${ }^{16}$ To avoid framing effects, the questions on job motivation and reciprocity were not placed directly after questions on retirement expectations. The question on job motivation was placed after a block of questions on training participation. The reciprocity questions were placed after a block of health questions.
} 
(4.3 to 3.7). A substantial number of respondents report that the statements on positive reciprocity apply to them perfectly, while respondents identify on average, less with the statements on negative reciprocity. The variance within the negative reciprocity measures is larger than within the positive reciprocity measures. ${ }^{17}$

Table 1 also reports summary statistics for our two reciprocity measures, which are constructed by averaging agreement with the three statements concerning positive and negative reciprocity respectively. Again, there are no differences in reciprocal behavior between the treatment and control groups according to these measures. There are also no significant between-group differences in the other attributes used in our analyses below, annual wage income, the number of years during which workers have built up their pension, marital status, self-reported health status, educational attainment, and the employment subsector.

Figure 1 plots local polynomial estimates of job motivation on birth date for the treatment and control groups together, with $95 \%$ confidence intervals, and reveals that younger cohorts are more motivated, on average. Most importantly, there is a drop in job motivation around the birth date that divides public sector employees into treatment and control groups. This drop in job motivation for workers who were born just after 1949 suggests a causal impact of the retrenchment of pension rights on the level of job motivation. These regression lines indicate that the discontinuity around the birth date January 1, 1950, is significant. Ascribing the reduction in job motivation to the retrenchment of pension rights requires that the employees in our sample be aware of the drop in pension rights brought about by the change in law. To verify this, we compare expectations of the level of pension benefits across the treatment and control groups with the following question: 'Suppose, you retired at the age of 62 . How large will your pension benefit be as a percentage of your net wage income?' The average responses shown in Table 1 make it clear that respondents who are affected by the pension reform indeed expect a

\footnotetext{
${ }^{17}$ Reassuringly, the distributions of the answers to the six reciprocity questions exhibit very similar patterns tho those of respondents' answers in the SOEP (Dohmen et al., 2009).
} 
significantly lower replacement rate. The mean difference in expected retirement benefits between the treatment and control groups amounts to five percentage points, which is remarkably close to the actual mean difference between those groups (6\%). Therefore, we can reasonably conclude that employees are aware of the consequences of the new pension system.

\subsection{Self-selection}

A relevant issue is whether our outcomes are affected by self-selection. We have to acknowledge that non-respondents may have different characteristics than those who filled in the questionnaire, and therefore our results may not be perfectly generalizable to the entire male population of public sector workers born in 1949 or 1950. In this respect, the natural experimental approach used here does not differ from the approach of other studies that use non-experimental survey data. However, a much greater problem would be when the non-response differs between the treatment and control group. For example, when among the treated, those who feel the strongest about the reform, arguably the most negatively reciprocal, do respond more often. In that situation, the similarity of the two groups is no longer guaranteed, and the regression discontinuity design loses its internal validity. We therefore examined in detail the similarity of the treated and untreated respondents.

We are confident that the non-response does not differ between the treatment and control group because of several reasons. First, as already mentioned before, the potential participants were not informed about the nature of our question and research strategy, and the invitation letter, as well as the survey itself, did not include references to the pension reform. Second, we checked whether there were deviations in the survey participation rate between the treatment and control groups. For each year, the differences in participation rates are extremely small. In $2007,30.5 \%$ of all the workers in the treatment group participated in the survey, versus $31.0 \%$ among the control group. In 
2008, the survey participation rates were $21.6 \%$ for the treatment group and $22.2 \%$ for the control group. Simple t-tests show that these small differences in the participation rates are statistically insignificant, with t-statistics of 0.97 in 2007 and 1.20 in 2008. Simple probit analyses also confirm that selection into the survey in both survey waves was not related to the treatment. These probit analyses include several control variables available from the administrative data, such as work sector, contractual work hours, birth month, and yearly wage (in logs). Third, we found no evidence in Table 1 that the treated and untreated respondents differ in their observable characteristics. Both job and personal characteristics are similar across the two groups and not significantly different from each other.

Finally, Table 1 showed that there are no significant differences in the average responses of both groups to each of the six different reciprocity measures and the averages of the three statements concerning positive and negative reciprocity. Furthermore, Figures A1-A4 in the Appendix show that the distributions of the averages of our positive and negative reciprocity indicators are strikingly similar for the treatment and control groups. This indicates that negatively treated workers, who arguably feel the strongest about the reform, did not more often respond to the questionnaire, and that our regression discontinuity approach is internally valid.

\section{Estimation Results}

\subsection{Job Motivation, Treatment and Negative Reciprocity}

We start our analysis by estimating ordinary least squares (OLS) regressions in which we relate job motivation to a treatment dummy that takes the value one if the employee was affected by the retrenchment in pension rights (i.e., born in 1950), and zero otherwise; the measures of negative and positive reciprocity; two interaction terms between the measures of reciprocity and the treatment dummy; and a set of control variables (including age, 
annual wage income (in logs), the number of years in which workers have built up their pension, marital status, self-reported health status, educational attainment, and employment subsector). Since we have a sharp discontinuity in pension rights and observe only a small age difference between the treated and control groups, this is equivalent to a regression discontinuity approach (Van der Klaauw, 2002). Our coefficient of interest is the coefficient of the interaction between negative reciprocity and the treatment dummy. This coefficient captures differential responses in job motivation by treated workers depending on their negatively reciprocal inclinations. Column 1 of Table 2 shows that the treatment effect is indeed heterogeneous with respect to reciprocal behavior. The coefficient of the interaction effect is negative and statistically significantly different from zero, indicating that the negative treatment effect is significantly stronger for the negatively reciprocal workers. ${ }^{18}$

An increase of one standard deviation in the negative reciprocity scale (0.79) reduces the job motivation of treated workers by 0.101 , equivalent to having an annual wage that is $0.5 \%$ lower. We also find, as can be expected, that the interaction between positive reciprocity and the treatment variable has no effect on the level of job motivation. Table 2 shows that negative reciprocity generally reduces the job motivation of all workers significantly, while positive reciprocity has no significant impact. Employees with bad health and those who increased their pension savings in the previous year are less motivated while job motivation is positively correlated with wage income and being married.

Columns 2 to 4 of Table 2 shows that our key result, that the reduction in job motivation of workers whose pension rights are curbed depends on the level of their negatively reciprocal inclinations, is robust to the inclusion of higher-order age polynomials. Column 5 further shows that this result is robust to the inclusion of interaction terms between

\footnotetext{
${ }^{18} \mathrm{We}$ also estimated the impact of unfair treatment on job motivation for the different quartiles of the distribution of negative reciprocity. The comparison of the treatment dummy across the different quartiles confirms that the treatment effect is heterogenous with respect to reciprocal behavior: The difference in job motivation is highest and statistically significant among treated workers in the upper quartile of the negative reciprocity distribution, and lowest among the least negatively reciprocal treated workers.
} 
our measures for negative or positive reciprocity and age. ${ }^{19}$ Table A1 in the Appendix shows that this result is also robust to the estimation technique: Ordered probit estimates that deal with the discreteness of job motivation lead to exactly the same conclusion. ${ }^{20}$ Furthermore, Table A2 in the Appendix shows that the interaction effect between the three separate individual negative reciprocity items and the treatment dummy on job motivation is significant for all three items. ${ }^{21}$

\subsection{Perceived Unfairness of Policy Change}

Until now, we have implicitly presupposed that the perceived unfairness brought about by the retrenchment in pension rights is the same among all treated workers. However, there may be differences in perceived unfairness. We would expect that those who feel treated most unfairly among the negative reciprocal to react more strongly to the policy change. Unfortunately, we do not have a direct measure of perceived unfairness, but it is plausible to assume that workers who were born only shortly after the treatment threshold perceive the policy change as more unfair; they compare their pension rights to the rights of those born just a few days earlier but who still enjoy the older more generous plan. Accordingly, we expect that strongly negatively reciprocal workers in this specific group will be more demotivated than workers born later in 1950.

We test this conjecture by comparing the job motivation of workers born in different quarters in $1950 .^{22}$ The treatment group in Column 1 of Table 3 consists of workers who

\footnotetext{
${ }^{19}$ The policy has an impact only on the workers who choose the early retirement scheme. Because most workers retired at the age of 62 or younger before 2006, they are indeed curtailed in their early retirement plans. However, we included the expected retirement age and its interaction with negative reciprocity in an additional analysis to control for early retirement preferences. We find that the coefficient of the interaction between treatment and negative reciprocity is robust to the inclusion of these variables.

${ }^{20}$ The results are also robust to the use of a semi-nonparametric estimator for a series of generalized models that nest the ordered probit model and thereby relaxes the distributional assumptions in that model (see Stewart, 2004).

${ }^{21}$ In additional robustness checks we investigate whether our results are sensitive to the construction of our reciprocity measures. We estimate ordered probit models, including alternative measures of negative and positive reciprocity constructed based on principal component analysis on the six underlying items, and find that the interaction effect between negative reciprocity and the treatment group remains highly significant.

${ }^{22}$ We also checked whether the effect of the interaction between the treatment dummy and negative reciprocity can be attributed to the seasonality of birth by performing additional estimations on a sample
} 
were born in the first quarter of 1950 and the control group consists of those born in the fourth quarter if 1949, while the treatment group in Column 2 consists of workers born in the second, third or fourth quarter of 1950. The bandwidth selection in Column 1 corresponds to the optimal bandwidth which we derived by implementing the procedure of Imbens and Kalyanaraman (2012). This procedure enables the calculation of the optimal bandwidth for regression discontinuity designs through the minimization of an expected squared error loss criterion. ${ }^{23}$

Tabel 3 shows that our results are robust to applying a smaller bandwidth and confirms our expectation that negatively reciprocal workers born on or just after January 1 , 1950, are more demotivated than workers born later in the year. The coefficient of the interaction term between negative reciprocity and the treatment variable is substantial and significant in Column 1, while the negative effect for workers born in later quarters of 1950 is smaller (Column 2). However, the difference between the coefficients in both regressions is not statistically significant. ${ }^{24}$

It is also intuitive to assume that the extent to which colleagues in a worker's organization suffer from the reform affects the perceived fairness of the policy change. Since workers tend to compare the rewards of their efforts to those their colleagues receive, we conjecture that treated employees suffer more from the reform the higher the fraction of untreated employees working in their organization (see also Fliessbach et al., 2007; Clark and Senik, 2010; Gächter, et al., 2012). To construct a proxy for the degree of social comparison, we rely on administrative data to calculate for each public sector organization

of workers born in the first quarter of 1949 or the first quarter of 1950 . We find that the interaction effect between reciprocity and the treatment dummy remains strongly significant and therefore seasonality of birth is not likely to be the main determinant of the significant interaction effect.

${ }^{23}$ The idea behind the procedure of Imbens and Kalyanaraman is that the optimal bandwidth should increase when the variance in outcomes increases at the cut-off, when the density of the forcing variable (age) is smaller, or when the shapes of the curves on both sides of the cut-off becomes increasingly symmetrical.

${ }^{24}$ It is conceivable that the treatment effect depends not only on reciprocal motivation, but also on the assessment of workers of their own pension rights. We would expect that treated workers who expect a relatively low pension may be more demotivated by the retrenchment of their pension rights. We therefore have run separate regression analyses for workers who expect that their pension benefit at age 62 are equal or above the median for each subgroup, and for those who expect their pension benefits to be below the median. We found indeed that job motivation is most reduced among treated negative reciprocal workers who have low expectations of their pension rights. 
the fraction of untreated employees born in 1949 and the total number of workers in the organization. ${ }^{25}$ We then run separate regressions for workers in organizations whose share of untreated workers is below the median, and for those in organizations whose share of untreated workers is at or above the median. Table 4 shows that the coefficient of the interaction term between the treatment dummy and the negative reciprocity measure is almost twice as large for the group of workers who have a higher share of colleagues who are unaffected by the reform. This finding corroborates the hypothesis that the perception of being treated unfairly causes negatively reciprocal employees to retaliate against their employer by providing less effort.

\subsection{The Employer - Employee Relation}

Employer accountability for unfair treatment is a pre-condition for the directed retaliation of workers. We therefore expect negatively reciprocal workers who hold their employer responsible for unfair treatment to purposefully retaliate against their employer. It is very likely that public sector employees hold their employer responsible for the retrenchment of pension rights, because the government, which is regarded as the public sector's corporate management, initiated the pension reform by abolishing the favorable tax treatment. This accountability in management is an important reason for focusing on public sector employees. Nevertheless, it seems straightforward to conjecture that the extent to which employees hold their employer responsible may differ across the different Dutch public subsectors. ${ }^{26}$ Since the national government initiated the policy reform, it is plausible to conjecture that civil servants who work for the national government most strongly assign the blame for the unfair treatment directly to their own employer. Consequently,

\footnotetext{
${ }^{25}$ Unfortunately, we do not have administrative data on the age distribution of the total workforce in organizations. We can therefore only look at the fraction of untreated employees who were born in 1949.

${ }^{26}$ The 15 subsectors are the following: the national government departments; defense (only civilian personnel); provinces, municipalities; the judiciary; primary and secondary education, intermediate vocational education; higher vocational education; universities; the research and scientific policy sector; teaching hospitals; district water boards; water, energy and public utilities; voluntary members (including $\mathrm{ABP}$ and public transport) and a remaining category.
} 
we expect that the treatment effect is greater among negatively reciprocal workers in the government departments.

Estimating the impact of the reform separately for workers employed in the national government departments and those in the remaining public subsectors, we find that the coefficient of the interaction between the treatment term and our indicator for negative reciprocity is much greater for employees in the government departments than in other sectors, as a comparison of OLS estimates in Columns 1 and 2 of Table 5 reveals. This confirms the conjecture that employees who can directly associate the unfair treatment to their own employer, show stronger negative reciprocal behavior through a reduction in job motivation.

\subsection{Robustness}

\subsubsection{Alternative Productivity Indicator}

We have looked at job motivation as a proxy of work effort since it is difficult to measure work effort directly. Alternatively, one can argue that reduced work effort should be reflected in reduced productivity and therefore aim for a direct assessment of the input of negatively reciprocal individuals among the treated group on productivity. It is difficult, however, to measure individual productivity in the public sector. Using the same data as we use, De Grip et al. (2012) recently showed that the unexpected drop in pension rights increases the likelihood of becoming depressed. Since depression affects productivity by causing mistakes at work, faulty products as well as increased sickness absence (see OECD, 2008), a mental health variable may serve as a useful alternative indicator for productivity. Moreover, we can assume that workers who are more negatively reciprocal and therefore have strong negative emotions when affected by the reform also become more depressed. ${ }^{27}$ Column 1 of Table A3 in the Appendix reports the estimation results

\footnotetext{
${ }^{27}$ To measure mental health, De Grip et al. (2012) used the CES-D8 indicator of depression, which is derived from the Center for Epidemiologic Studies Depression Scale. The CES-D8 consists of eight items, six of which are negatively phrased statements that reflect the presence of depressive symptoms, and two
} 
of a lineair probability model regression on the depression indicator. We find that workers in the treatment group who are strongly negatively reciprocal are indeed more depressed (the coefficient of the interaction dummy equals 0.012 , with a standard error of 0.005 ) than less negatively reciprocal workers, thus confirming our results on job motivation.

\subsubsection{Workers with Career Breaks}

The results of further robustness checks shown in Table A4 in the Appendix buttress our findings. This analysis includes workers with career breaks after April 1997. Although it is conceivable that these worker's career interruptions were caused by unobserved individual characteristics that may also be related to reciprocal behavior, the inclusion of these workers introduces an additional treatment group. Remember that the legislative change also curtailed the pensions of those born in 1949 and before if they did not work continuously in the public sector since April, 1997. Column 1 presents estimation results only for workers born in 1949. The treatment dummy equals one for workers born in 1949, but not entitled to the old pension rights since they did not work continuously since April 1997, whereas the dummy is zero for all workers in 1949 who remain entitled. The estimation results show a significant and negative coefficient of the interaction between the treatment variable and negative reciprocity. Therefore, for this specific treatment group as well, we find that primarily negatively reciprocal workers with curtailed pension rights are strongly demotivated.

Column 2 of Table A4 contains estimation results for the full 1949 and 1950 sample and includes two treatment dummy variables. The first treatment dummy equals one for workers born in 1949 and not entitled to the old pension rights, and zero otherwise. The

positively phrased statements that reflect the absence of depressive symptoms. To create the variable used in our analyses, we first dichotomized (yes/no) responses and reversed coding of the positively phrased items to achieve a count variable from 0 to 8 , with higher values suggesting worsening depressive symptoms. In the next step, we constructed a dummy variable indicating whether workers are depressed. Following De Grip et al. (2012) we used the suggested score of 4 and above to indicate probable clinical depression. Validation studies have shown that this cut-off score for the CES-D8 scale is optimal for determining clinical depression, and is equivalent to the standard cut-off point of 16 for the full CES-D scale (Blazer et al., 1991; Andresen et al., 1994; Beekman et al., 1995; Steffick, 2000; Reyes-Gibby et al., 2002). Using lower cut-off scores will lead to a substantial over-estimation of the number of depressed individuals, while the gains of applying a higher cut-off are limited (Beekman et al., 1995). 
second treatment dummy equals one if the workers were born in 1950, and zero if born in 1949. The estimation results show that both interactions between the treatment dummy variables and negative reciprocity are negative and significantly different from zero. The negatively reciprocal workers of the 1949 treatment group appear to be slightly more demotivated than those who are in the 1950 treatment group; however, the difference between the two coefficients is insignificant at the $5 \%$ level.

\section{Conclusion}

This paper shows that reciprocity is an important determinant of job motivation. Using a natural experiment, we find that a decrease in pension rights is associated with lower job motivation among negatively reciprocal employees. Moreover, negatively reciprocal workers born in the first three months of 1950 are more demotivated than those born later in the year, plausibly because the former perceive the differential tax treatment as more unfair because their age hardly differs from that of those not affected by the reform. Moreover, we observe that the coefficient of the interaction term between the treatment dummy and negative reciprocity is substantial larger for workers confronted with a higher share of colleagues with similar characteristics who are not covered by the reform. We also find that negatively reciprocal workers employed in the national government, and who can this directly associate their unfair treatment to their own employer, have lower job motivation than those employed in other public subsectors. Our results are robust to the use of alternative estimation methods and different indicators of productivity.

Our findings complement earlier experimental evidence. In accordance with an ultimatum game, the drop in motivation can be interpreted as the sanctioning of unkind or hostile actions (e.g. Güth et al., 1982; Camerer and Thaler, 1995). Our evidence shows that negatively reciprocal individuals not only sanction actions they perceive as unkind or hostile in laboratory settings, but also behave similarly when they feel treated unfairly by their employers. Consequently, the intended effects of pension reforms that aim to 
increase labor force participation can be distorted by the decreasing job motivation of negatively reciprocal workers who feel unfairly treated. Therefore, it is crucial to think of reform designs that provide less scope for being perceived as unfair by particular groups. In the specific example of tax legislation affecting pension rights, an alternative design that entails smaller discontinuous differences in pension rights would arguably cause less disruption in terms of negatively reciprocal responses.

\section{References}

Akerlof, G.A. (1982). 'Labor contracts as partial gift exchange.' Quarterly Journal of Economics 97(4), 543-569.

Andresen, E.M., J.A. Malmgren, W.B. Carter, and D.L. Patrick (1994). 'Screening for depression in well older adults: Evaluation of a short form of the CES-D (Center for Epidemiologic Studies Depression Scale).' American Journal of Preventive Medicine vol. $10(2)$, pp. $77-84$.

Beekman, A., D. Deeg, T. van Tilburg, J. Smit, C. Hooijer, and W. van Tilburg (1995). 'Major and minor depression in later life: a study of prevalence and risk factors.' Journal of Affective Disorders vol. 36, pp. 65-75.

Bellemare, C., and B. Shearer (2009). 'Gift giving and worker productivity: evidence from a firm-level experiment.' Games and Economic Behavior 67, 233-244.

Bellemare, C., and S. Kröger (2007). 'On representative social capital.' European Economic Review 51, 183-202.

Berg, J., J. Dickhaut, and K. McCabe (1995). 'Trust, reciprocity and social history.' Games and Economic Bahavior 10, 122-142. 
Blazer, D., B. Burchett, C. Service, and L.K. George (1991). 'The association of age and depression among the elderly: An epidemiologic exploration.' Journal of Gerontology vol. 46(6), pp. M210-215.

Bowles, S. (2008). 'Policies designed for self interested citizens may undermine the moral sentiments.' Science 320, 1605-1609.

Bowles, S., H. Gintis, and M. Osborne (2001). 'The determinants of earnings: Skills, preferences, and schooling.' Journal of Economic Literature 39, 1137-1176.

Brown, M., A. Falk, and E. Fehr (2004). 'Relational contracts and the nature of market interactions.' Econometrica 72, 747-780.

Brown, S., and T. Leigh (1996). 'A new look at psychological climate and its relationship to job involvement, effort and performance.' Journal of Applied Psychology 81, 358-368.

Camerer, C.F., and R. Hogarth (1999). 'The effects of financial incentives in experiments: A review and capital-labor-production framework.' Journal of Risk and Uncertainty $19,7-42$.

Camerer, C.F., and R. Thaler (1995). 'Ultimatums, dictators and manners.' Journal of Economic Perspectives 9, 209-219.

Clark, A.E., and C. Senik (2010). 'Who compares to whom? the autonomy of income comparisons in Europe.' The Economic Journal 120, 573-594.

Cohn, A., E. Fehr, and L. Goette (2009). 'Fairness and effort: Evidence from a field experiment.' Unpublished

De Grip, A., M. Lindeboom, and R. Montizaan (2012). 'Shattered dreams: The effects of changing the pension system late in the game.' The Economic Journal 122, 1-25.

Dohmen, T., A. Falk, D. Huffman, and U. Sunde (2009). 'Homo reciprocans: Survey evidence on behavioral outcomes.' The Economic Journal 119, 592-612. 
Dohmen, T., A. Falk, D. Huffman, U. Sunde, J. Schupp, and W. Wagner (2011). 'Individual risk attitudes: Measurement, determinants and behavioral consequences.' Journal of the European Economic Association 9, 522-550.

Duncan, G., and R. Dunifon (1997). 'Long-run effects of motivation on labor-market success.' Social Psychology Quarterly 61, 33-48.

Euwals, Rob W., Daniël J. van Vuuren, and Ronald P. Wolthoff (2006). 'Early retirement behaviour in the Netherlands: Evidence from a policy reform.' Tinbergen Institute Discussion Paper 2006-021/3

Falk, A. (2007). 'Gift exchange in the field.' Econometrica 75, 1501-1511.

Falk, A., and C. Zehnder (2007). 'Discrimination and in-group favoritism in a citywide trust experiment.' IZA Discussion paper 2765

Fehr, E., and S. Gächter (2000). 'Fairness and retaliation.' Journal of Economic Perspectives 14, 159-181.

Fehr, E., G. Kirchsteiger, and A. Riedl (1993). 'Does fairness prevent market clearing? an experimental investigation.' Quarterly Journal of Economics 108, 437-460.

_ (1998). 'Gift exchange and reciprocity in competitive experimental markets.' European Economic Review 42, 1-34.

Fehr, E., L. Goette, and C. Zehnder (2009). 'A behavioral account of the labor market: The role of fairness concerns.' Annual Review of Economics 1, 355-384.

Fehr, E., U. Fischbacher, B. von Rosenbladt, J. Schupp, and G.G. Wagner (2003). 'A nation-wide laboratory: Examining trust and trustworthiness by integrating behavioral experiments into representative surveys.' IZA Discussion paper 715 
Fliessbach, K., B. Weber, P. Trautner, T. Dohmen, U. Sunde, C. Elger, and A. Falk (2007). 'Social comparison affects reward-related brain activity in the human ventral striatum.' Science 318, 1305-1308.

Gächter, S., D. Nosenzo, and M. Sefton (2012). 'Peer effects in pro-social behavior: Social norms or social preferences?' Forthcoming in the Journal of the European Economic Association

Gneezy, U., and J. List (2006). 'Putting behavioral economics to work: testing for gift exchange in labor markets using field experiments.' Econometrica 74, 1365-1384.

Güth, W., R. Schmittberger, and B. Schwarze (1982). 'An experimental analysis of ultimatum bargaining.' Journal of Economic Behavior and Organization 3, 367-388.

Imbens, G., and K. Kalyanaraman (2012). 'Optimal bandwidth choice for the regression discontinuity estimator.' Forthcoming in Review of Economic Studies

Imbens, G., and T. Lemieux (2008). 'Regression discontinuity designs: A guide to practice.' Journal of Econometrics 142, 615-635.

Judge, T., C. Thoresen, and J. Bono andG. Patton (2001). 'The job satisfaction-job performance relationship: A qualitative and quantitative review.' Psycholocial Bulletin 127, 376-407.

Kooiman, P., Rob W. Euwals, M. van de Ven, and Daniël J. van Vuuren (2004). 'Price and income incentives in early retirement: A preliminary analysis of a Dutch pension reform.' paper presented at the NERO 2004 meeting

Krueger, A.B., and A. Mas (2004). 'Strikes, scabs and tread seperations: Labor strife and the production of defective Bridgestone/Firestone Tires.' Journal of Political Economy $112,253-289$.

Kube, S., M. Marchal, and C. Puppe (2012a). 'The currency of reciprocity-gift-exchange in the workplace.' American Economic Review 102, 1644-1662. 
_ (2012b). 'Do wage cuts damage work morale? Evidence from a natural field experiment.' Forthcoming in the Journal of the European Economic Association

Lee, D.S., and T. Lemieux (2010). 'Regression discontinuity designs in economics.' Journal of Economic Literature 48, 281-355.

Montizaan, R., and M. Vendrik (2012). 'Shocks in retirement expectations and subjective well-being: evidence from a natural experiment.' IZA discussion paper 6863

OECD (2008). 'Employment outlook.' Paris, OECD

Perugini, M., M. Gallucci, F. Presaghi, and A.P. Ercolani (2003). 'The personal norm of reciprocity.' European Journal of Personality 17, 251-283

Rabin, M. (1993). 'Incorporating fairness into game theory and economics.' American Economic Review 83, 1281-1302

Reyes-Gibby, C., L. Aday, and C. Cleeland (2002). 'Impact of pain on self-rated health in the community-dwelling older adults.' Pain vol. 95(1-2), pp. 75-82.

Statistics Netherlands (2009). 'Labour force survey.' Statline

Steffick, ED. (2000). 'Documentation of affective functioning measures in the health and retirement study.' HRS/AHEAD Documentation Report, Ann Arbor: Survey Research Center University of Michigan

Stewart, M.B. (2004). 'Semi-nonparametric estimation of extended ordered probit models.' The Stata Journal 4, 2739.

Van der Klaauw, W. (2002). 'Estimating the effect of financial aid offers on college enrollment: A regression-discontinuity approach.' International Economic Review 43(4), pp. $1249-1287$. 
Table 1

Descriptive statistics

\begin{tabular}{|c|c|c|c|c|}
\hline & $\begin{array}{c}\text { Entire } \\
\text { sample }\end{array}$ & $\begin{array}{c}\text { Born in } \\
1949\end{array}$ & $\begin{array}{c}\text { Born in } \\
1950\end{array}$ & P-value \\
\hline Take revenge for a serious wrong & $\begin{array}{c}3.06 \\
(1.04)\end{array}$ & $\begin{array}{c}3.06 \\
(1.04)\end{array}$ & $\begin{array}{c}3.06 \\
(1.05)\end{array}$ & 0.78 \\
\hline Retaliate for being put in a difficult position & $\begin{array}{c}2.54 \\
(0.85)\end{array}$ & $\begin{array}{c}2.54 \\
(0.84)\end{array}$ & $\begin{array}{c}2.54 \\
(0.86)\end{array}$ & 0.89 \\
\hline Reciprocate insult with an insult & $\begin{array}{c}2.60 \\
(0.91)\end{array}$ & $\begin{array}{c}2.60 \\
(0.90)\end{array}$ & $\begin{array}{c}2.62 \\
(0.91)\end{array}$ & 0.85 \\
\hline Reciprocate a favor & $\begin{array}{c}4.29 \\
(0.64)\end{array}$ & $\begin{array}{c}4.31 \\
(0.63)\end{array}$ & $\begin{array}{c}4.27 \\
(0.64)\end{array}$ & 0.08 \\
\hline Exert effort to help somebody who is kind & $\begin{array}{c}4.11 \\
(0.62)\end{array}$ & $\begin{array}{c}4.11 \\
(0.62)\end{array}$ & $\begin{array}{c}4.11 \\
(0.62)\end{array}$ & 0.80 \\
\hline Undergo personal costs to help someone who was helpful before & $\begin{array}{c}3.73 \\
(0.70)\end{array}$ & $\begin{array}{c}3.73 \\
(0.69)\end{array}$ & $\begin{array}{c}3.72 \\
(0.71)\end{array}$ & 0.15 \\
\hline Negative reciprocity (averaged) & $\begin{array}{c}2.73 \\
(0.79)\end{array}$ & $\begin{array}{c}2.74 \\
(0.78)\end{array}$ & $\begin{array}{c}2.73 \\
(0.79)\end{array}$ & 0.96 \\
\hline Positive reciprocity (averaged) & $\begin{array}{c}4.04 \\
(0.51)\end{array}$ & $\begin{array}{c}4.05 \\
(0.50)\end{array}$ & $\begin{array}{c}4.04 \\
(0.51)\end{array}$ & 0.13 \\
\hline Expected retirement benefit at age of 62 (in $\%$ of net present wage) & $\begin{array}{c}69.02 \\
(11.67)\end{array}$ & $\begin{array}{c}71.66 \\
(11.67)\end{array}$ & $\begin{array}{c}66.62 \\
(11.14)\end{array}$ & 0.00 \\
\hline Extra pension savings in previous year ( 1 if savings increased) & $\begin{array}{c}0.25 \\
(0.43)\end{array}$ & $\begin{array}{c}0.22 \\
(0.41)\end{array}$ & $\begin{array}{c}0.27 \\
(0.44)\end{array}$ & 0.00 \\
\hline Yearly wage (in euros) & $\begin{array}{c}53,132 \\
(16,420)\end{array}$ & $\begin{array}{c}53,132 \\
(15,957)\end{array}$ & $\begin{array}{c}53,131 \\
(16,938)\end{array}$ & 0.30 \\
\hline Log size of organization & $\begin{array}{c}7.13 \\
(1.78)\end{array}$ & $\begin{array}{c}7.13 \\
(1.79)\end{array}$ & $\begin{array}{c}7.13 \\
(1.77)\end{array}$ & 0.59 \\
\hline Marital status ( 1 if married) & $\begin{array}{c}0.92 \\
(0.28)\end{array}$ & $\begin{array}{c}0.92 \\
(0.27)\end{array}$ & $\begin{array}{c}0.91 \\
(0.29)\end{array}$ & 0.08 \\
\hline Bad health (self reported on 5-point Likert scale) & $\begin{array}{c}2.06 \\
(0.72)\end{array}$ & $\begin{array}{c}2.07 \\
(0.72)\end{array}$ & $\begin{array}{c}2.05 \\
(0.72)\end{array}$ & 0.45 \\
\hline Number of observations & 4,520 & 2,147 & 2,373 & \\
\hline
\end{tabular}

Sample standard deviations are in parentheses below sample averages. The measure of negative reciprocity is the individual's agreement to the three statements on the willingness to take revenge for a serious wrong, to retaliate for being put in a difficult position and to respond to an insult with an insult. The measure of positive reciprocity reflects the agreement to statements on the willingness to return a favor; to exert effort to somebody who was kind; and to undergo personal costs to help someone who was helpful before. Both measures are based on the average of the three underlying items. Answers for the six reciprocity questions are on a five-point Likert scale between 1 to 5 with 1 meaning 'does not apply to me at all' and 5 means 'applies perfectly to me'. The expected retirement benefit at age of 62 is based on the following survey question: 'Suppose you would retire at the age of 62 . How large would your pension benefit be in percentage of your net wage income?' The yearly wage income is based on administrative data of the public sector's pension fund. 
Table 2

Negative reciprocity, treatment and job motivation: OLS estimates

\begin{tabular}{|c|c|c|c|c|c|}
\hline Dependent variable: Job motivation & (1) & $(2)$ & (3) & (4) & $(5)$ \\
\hline \multirow[t]{2}{*}{ Interaction treatment and negative reciprocity } & $-0.129^{* * *}$ & $-0.128^{* * *}$ & $-0.128 * * *$ & $-0.128^{* * *}$ & $-0.165^{* *}$ \\
\hline & $(0.042)$ & $(0.042)$ & $(0.042)$ & $(0.042)$ & $(0.082)$ \\
\hline \multirow[t]{2}{*}{ Interaction treatment and positive reciprocity } & -0.026 & -0.025 & -0.025 & -0.025 & -0.033 \\
\hline & $(0.065)$ & $(0.065)$ & $(0.065)$ & $(0.065)$ & $(0.130)$ \\
\hline \multirow[t]{2}{*}{ Negative reciprocity } & $-0.093^{* * *}$ & $-0.094^{* * *}$ & $-0.094^{* * *}$ & $-0.094^{* * *}$ & -0.037 \\
\hline & $(0.031)$ & $(0.031)$ & $(0.031)$ & $(0.031)$ & $(0.113)$ \\
\hline \multirow[t]{2}{*}{ Positive reciprocity } & -0.000 & -0.001 & -0.001 & -0.001 & 0.011 \\
\hline & $(0.048)$ & $(0.048)$ & $(0.048)$ & $(0.048)$ & $(0.176)$ \\
\hline \multirow[t]{2}{*}{ Treatment dummy } & 0.427 & 0.300 & 0.301 & 0.272 & 0.433 \\
\hline & $(0.272)$ & $(0.278)$ & $(0.278)$ & $(0.285)$ & $(0.545)$ \\
\hline \multirow[t]{2}{*}{ Number of years contributed to the pension fund } & -0.004 & -0.004 & -0.004 & -0.004 & -0.004 \\
\hline & $(0.003)$ & $(0.003)$ & $(0.003)$ & $(0.003)$ & $(0.003)$ \\
\hline \multirow[t]{2}{*}{ Log yearly wage } & $0.202^{* *}$ & $0.202^{* *}$ & $0.203^{* *}$ & $0.204^{* *}$ & $0.202^{* *}$ \\
\hline & $(0.086)$ & $(0.086)$ & $(0.086)$ & $(0.086)$ & $(0.086)$ \\
\hline \multirow[t]{2}{*}{ Log size of organization } & 0.004 & 0.004 & 0.004 & 0.004 & 0.004 \\
\hline & $(0.015)$ & $(0.015)$ & $(0.015)$ & $(0.015)$ & $(0.015)$ \\
\hline \multirow[t]{2}{*}{ Marital status } & $0.100^{*}$ & $0.103^{*}$ & $0.104^{*}$ & $0.104^{*}$ & $0.104^{*}$ \\
\hline & $(0.059)$ & $(0.059)$ & $(0.059)$ & $(0.059)$ & $(0.059)$ \\
\hline \multirow[t]{2}{*}{ Bad health } & $-0.408^{* * *}$ & $-0.407^{* * *}$ & $-0.407^{* * *}$ & $-0.407^{* * *}$ & $-0.407^{* * *}$ \\
\hline & $(0.023)$ & $(0.023)$ & $(0.023)$ & $(0.023)$ & $(0.023)$ \\
\hline \multirow[t]{2}{*}{ Age (in days divided by 365 ) } & & $-0.121^{* *}$ & -0.143 & 0.007 & 0.016 \\
\hline & & $(0.056)$ & $(0.120)$ & $(0.329)$ & $(0.471)$ \\
\hline \multirow[t]{2}{*}{$\mathrm{Age}^{2}$} & & & 0.011 & -0.201 & \\
\hline & & & $(0.054)$ & $(0.436)$ & \\
\hline \multirow[t]{2}{*}{$\mathrm{Age}^{3}$} & & & & 0.070 & \\
\hline & & & & $(0.143)$ & \\
\hline \multirow[t]{2}{*}{ Interaction age and negative reciprocity } & & & & & -0.038 \\
\hline & & & & & $(0.072)$ \\
\hline \multirow[t]{2}{*}{ Interaction age and positive reciprocity } & & & & & -0.008 \\
\hline & & & & & $(0.111)$ \\
\hline \multirow[t]{2}{*}{ Constant } & $2.255^{* *}$ & $2.443^{* *}$ & $2.446^{* *}$ & $2.446^{* *}$ & $2.238^{*}$ \\
\hline & $(0.969)$ & $(0.972)$ & $(0.972)$ & $(0.973)$ & $(1.213)$ \\
\hline Observations & 4,520 & 4,520 & 4,520 & 4,520 & 4,520 \\
\hline R-squared & 0.098 & 0.099 & 0.099 & 0.099 & 0.099 \\
\hline
\end{tabular}

The measures of negative and positive reciprocity used in the estimations are constructed by taking the average of the three underlying items. Additional control variables in the estimations are: educational levels; sector fixed effects. Standard errors are in parentheses. $* * *<0.01, * *<0.05, *<0.10$. 
Table 3

Treatment effect on job motivation: Results for different birth cohorts

\begin{tabular}{|c|c|c|}
\hline & (1) & $(2)$ \\
\hline Dependent variable: Job motivation & I 1950 vs IV 1949 & II-IV 1950 vs IV 1949 \\
\hline \multirow[t]{2}{*}{ Interaction treatment and negative reciprocity } & $-0.189 * *$ & $-0.141^{* *}$ \\
\hline & $(0.081)$ & $(0.070)$ \\
\hline \multirow[t]{2}{*}{ Interaction treatment and positive reciprocity } & -0.087 & 0.020 \\
\hline & $(0.130)$ & $(0.111)$ \\
\hline \multirow[t]{2}{*}{ Negative reciprocity } & -0.066 & -0.072 \\
\hline & $(0.061)$ & $(0.061)$ \\
\hline \multirow[t]{2}{*}{ Positive reciprocity } & -0.023 & -0.026 \\
\hline & $(0.098)$ & $(0.099)$ \\
\hline \multirow[t]{2}{*}{ Treatment dummy } & 0.723 & 0.227 \\
\hline & $(0.546)$ & $(0.469)$ \\
\hline \multirow[t]{2}{*}{ Number of years contributed to the pension fund } & -0.001 & -0.006 \\
\hline & $(0.005)$ & $(0.004)$ \\
\hline \multirow[t]{2}{*}{ Log yearly wage } & 0.115 & 0.143 \\
\hline & $(0.171)$ & $(0.124)$ \\
\hline \multirow[t]{2}{*}{ Log size of organization } & 0.004 & 0.031 \\
\hline & $(0.030)$ & $(0.021)$ \\
\hline \multirow[t]{2}{*}{ Marital status } & -0.070 & $0.159^{* *}$ \\
\hline & $(0.129)$ & $(0.081)$ \\
\hline \multirow[t]{2}{*}{ Bad health } & $-0.474^{* * *}$ & $-0.400 * * *$ \\
\hline & $(0.047)$ & $(0.032)$ \\
\hline \multirow[t]{2}{*}{ Constant } & $3.831^{* *}$ & $2.787^{*}$ \\
\hline & $(1.905)$ & $(1.464)$ \\
\hline Observations & 1,124 & 2,199 \\
\hline R-squared & 0.129 & 0.109 \\
\hline
\end{tabular}

OLS estimates. In Column 1, workers born in the first quarter of 1950 are compared to workers in the control group who were born in the fourth quarter of 1949 . Column 2 compares workers born in the second, third or fourth quarter of 1950 with those born in the fourth quarter of 1949. Additional control variables in both estimations are: educational levels; sector fixed effects. Standard errors are in parentheses. $* * *<0.01, * *<0.05, *<0.10$. 
Table 4

Treatment effect on job motivation: social comparisons

\begin{tabular}{|c|c|c|}
\hline & (1) & $(2)$ \\
\hline Dependent variable: Job motivation & $\begin{array}{c}\text { Percentage untreated } \\
\text { colleagues } \\
\text { above median }\end{array}$ & $\begin{array}{c}\text { Percentage untreated } \\
\text { colleagues } \\
\text { under median }\end{array}$ \\
\hline Interaction treatment and negative reciprocity & $\begin{array}{c}-0.180^{* * *} \\
(0.062)\end{array}$ & $\begin{array}{l}-0.097^{*} \\
(0.058)\end{array}$ \\
\hline Interaction treatment and positive reciprocity & $\begin{array}{l}-0.040 \\
(0.096)\end{array}$ & $\begin{array}{c}0.015 \\
(0.089)\end{array}$ \\
\hline Negative reciprocity & $\begin{array}{c}-0.091^{* *} \\
(0.043)\end{array}$ & $\begin{array}{c}-0.092^{* *} \\
(0.045)\end{array}$ \\
\hline Positive reciprocity & $\begin{array}{c}0.041 \\
(0.067)\end{array}$ & $\begin{array}{l}-0.051 \\
(0.069)\end{array}$ \\
\hline Treatment dummy & $\begin{array}{c}0.508 \\
(0.419)\end{array}$ & $\begin{array}{c}0.042 \\
(0.379)\end{array}$ \\
\hline Number of years contributed to the pension fund & $\begin{array}{l}-0.001 \\
(0.004)\end{array}$ & $\begin{array}{l}-0.005 \\
(0.004)\end{array}$ \\
\hline Log yearly wage & $\begin{array}{c}0.159 \\
(0.133)\end{array}$ & $\begin{array}{c}0.232^{* *} \\
(0.116)\end{array}$ \\
\hline Log size of organization & $\begin{array}{l}-0.014 \\
(0.021)\end{array}$ & $\begin{array}{c}0.027 \\
(0.022)\end{array}$ \\
\hline Marital status & $\begin{array}{c}0.138 \\
(0.092)\end{array}$ & $\begin{array}{c}0.088 \\
(0.077)\end{array}$ \\
\hline Bad health & $\begin{array}{c}-0.354^{* * *} \\
(0.034)\end{array}$ & $\begin{array}{c}-0.455^{* * *} \\
(0.031)\end{array}$ \\
\hline Age (in days divided by 365 ) & $\begin{array}{l}-0.097 \\
(0.082)\end{array}$ & $\begin{array}{c}-0.153^{* *} \\
(0.077)\end{array}$ \\
\hline Constant & $\begin{array}{l}2.716^{*} \\
(1.452)\end{array}$ & $\begin{array}{c}2.672^{* *} \\
(1.325)\end{array}$ \\
\hline Observations & 2,205 & 2,315 \\
\hline R-squared & 0.085 & 0.123 \\
\hline
\end{tabular}

All columns show results which are based on OLS estimates. We use administrative data on the total number of workers in the organization in which each employee is working to construct proxies for the incidence of social comparisons in the organization. We determine whether treated workers who were born in 1950 are working in an organization in which the group of untreated workers who were born in 1949 is comparatively large (percentage untreated above or under median). Additional control variables in the estimations are: educational levels; sector fixed effects. Standard errors are in parentheses. $* * *<0.01, * *<0.05, *<0.10$. 
Table 5

Treatment effect on job motivation: Heterogenous sector effects

\begin{tabular}{|c|c|c|}
\hline Dependent variable: Job motivation & $\begin{array}{c}(1) \\
\text { National } \\
\text { government }\end{array}$ & $\begin{array}{c}(2) \\
\text { Other } \\
\text { sectors }\end{array}$ \\
\hline Interaction treatment and negative reciprocity & $\begin{array}{c}-0.263^{* * *} \\
(0.096)\end{array}$ & $\begin{array}{c}-0.094^{* *} \\
(0.047)\end{array}$ \\
\hline Interaction treatment and positive reciprocity & $\begin{array}{l}-0.038 \\
(0.146)\end{array}$ & $\begin{array}{l}-0.018 \\
(0.072)\end{array}$ \\
\hline Negative reciprocity & $\begin{array}{l}-0.063 \\
(0.072)\end{array}$ & $\begin{array}{c}-0.096^{* * *} \\
(0.034)\end{array}$ \\
\hline Positive reciprocity & $\begin{array}{c}0.086 \\
(0.110)\end{array}$ & $\begin{array}{l}-0.034 \\
(0.053)\end{array}$ \\
\hline Treatment dummy & $\begin{array}{c}0.666 \\
(0.619)\end{array}$ & $\begin{array}{c}0.190 \\
(0.312)\end{array}$ \\
\hline Number of years contributed to the pension fund & $\begin{array}{c}0.005 \\
(0.007)\end{array}$ & $\begin{array}{l}-0.005^{*} \\
(0.003)\end{array}$ \\
\hline Log yearly wage & $\begin{array}{c}0.196 \\
(0.191)\end{array}$ & $\begin{array}{c}0.267^{* * *} \\
(0.091)\end{array}$ \\
\hline Log size of organization & $\begin{array}{c}0.014 \\
(0.030)\end{array}$ & $\begin{array}{l}-0.008 \\
(0.014)\end{array}$ \\
\hline Marital status & $\begin{array}{c}0.038 \\
(0.130)\end{array}$ & $\begin{array}{l}0.120^{*} \\
(0.066)\end{array}$ \\
\hline Bad health & $\begin{array}{c}-0.369^{* * *} \\
(0.053)\end{array}$ & $\begin{array}{c}-0.419 * * * \\
(0.025)\end{array}$ \\
\hline Age (in days divided by 365 ) & $\begin{array}{c}-0.250^{* *} \\
(0.124)\end{array}$ & $\begin{array}{l}-0.095 \\
(0.063)\end{array}$ \\
\hline Constant & $\begin{array}{c}1.673 \\
(2.139)\end{array}$ & $\begin{array}{l}2.009 * * \\
(1.005)\end{array}$ \\
\hline Observations & 961 & 3,559 \\
\hline R-squared & 0.095 & 0.099 \\
\hline
\end{tabular}

OLS estimates. Educational levels are included as control variables. Standard errors are in parentheses. $* * *<0.01, * *<0.05, *<0.10$. 
Figure 1 Job motivation

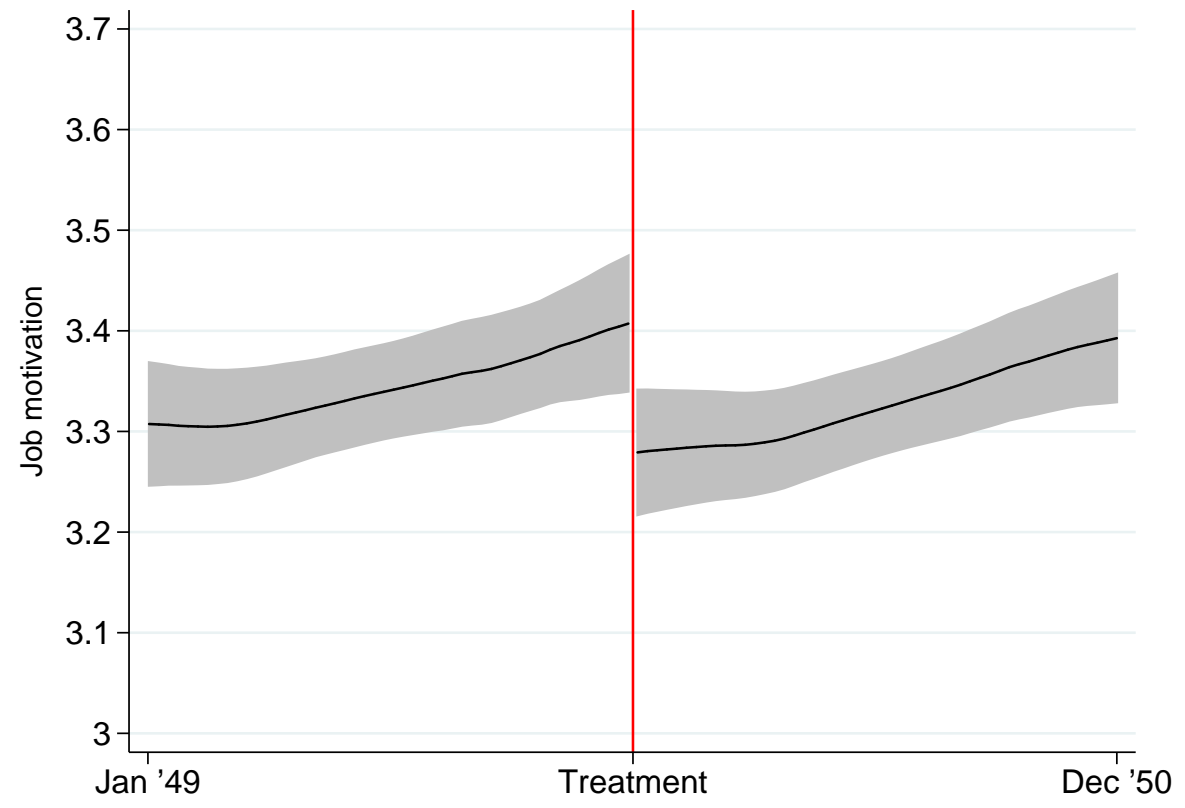

This figure presents a local polynomial smooth of job motivation on birth date with a $95 \%$ confidence interval, using a Epanechnikov kernel function. The bandwidth used for the kernel function corresponds to the optimal bandwidth derived from the Imbens and Kalyanaraman procedure (Imbens and Kalyanaraman, 2012). Job motivation is based on the following 5-level Likert item: 'At times, I have difficulties to motivate myself for my job'. Answers categories ranged form 1 ('does applies perfectly to me') to 5 ('does not apply to me at all'). Our sample consists of two birth years where workers born in 1949 are entitled to the old pension rules and workers born in 1950 are subject to the new pension rules. The vertical line in the figure marks the threshold which divides the control from the treatment group. 


\section{Appendix}

Table A1

Negative reciprocity, treatment and job motivation: Ordered Probit estimates

\begin{tabular}{|c|c|c|c|c|c|}
\hline Dependent variable: Job motivation & (1) & $(2)$ & $(3)$ & $(4)$ & $(5)$ \\
\hline \multirow[t]{2}{*}{ Interaction treatment and negative reciprocity } & $-0.128 * * *$ & $-0.127^{* * *}$ & $-0.127^{* * *}$ & $-0.127^{* * *}$ & $-0.164^{* *}$ \\
\hline & $(0.041)$ & $(0.041)$ & $(0.041)$ & $(0.041)$ & $(0.080)$ \\
\hline \multirow[t]{2}{*}{ Interaction treatment and positive reciprocity } & -0.034 & -0.034 & -0.034 & -0.034 & -0.063 \\
\hline & $(0.063)$ & $(0.063)$ & $(0.063)$ & $(0.063)$ & $(0.127)$ \\
\hline \multirow[t]{2}{*}{ Negative reciprocity } & $-0.096 * * *$ & $-0.098 * * *$ & $-0.098 * * *$ & $-0.098 * * *$ & -0.040 \\
\hline & $(0.030)$ & $(0.030)$ & $(0.030)$ & $(0.030)$ & $(0.110)$ \\
\hline \multirow[t]{2}{*}{ Positive reciprocity } & 0.016 & 0.016 & 0.016 & 0.015 & 0.060 \\
\hline & $(0.046)$ & $(0.047)$ & $(0.047)$ & $(0.047)$ & $(0.172)$ \\
\hline \multirow[t]{2}{*}{ Treatment dummy } & $0.464^{*}$ & 0.342 & 0.343 & 0.324 & 0.563 \\
\hline & $(0.265)$ & $(0.271)$ & $(0.271)$ & $(0.277)$ & $(0.532)$ \\
\hline \multirow[t]{2}{*}{ Number of years contributed to the pension fund } & -0.004 & -0.003 & -0.003 & -0.003 & -0.003 \\
\hline & $(0.003)$ & $(0.003)$ & $(0.003)$ & $(0.003)$ & $(0.003)$ \\
\hline \multirow[t]{2}{*}{ Log yearly wage } & $0.227^{* * *}$ & $0.227 * * *$ & $0.228^{* * *}$ & $0.228 * * *$ & $0.227^{* * *}$ \\
\hline & $(0.084)$ & $(0.084)$ & $(0.084)$ & $(0.084)$ & $(0.084)$ \\
\hline \multirow[t]{2}{*}{ Log size of organization } & 0.001 & 0.001 & 0.001 & 0.001 & 0.001 \\
\hline & $(0.014)$ & $(0.014)$ & $(0.014)$ & $(0.014)$ & $(0.014)$ \\
\hline \multirow[t]{2}{*}{ Marital status } & 0.093 & $0.096^{*}$ & $0.096^{*}$ & $0.096^{*}$ & $0.096^{*}$ \\
\hline & $(0.057)$ & $(0.057)$ & $(0.057)$ & $(0.057)$ & $(0.057)$ \\
\hline \multirow[t]{2}{*}{ Bad health } & $-0.397^{* * *}$ & $-0.397^{* * *}$ & $-0.397^{* * *}$ & $-0.397^{* * *}$ & $-0.396^{* * *}$ \\
\hline & $(0.023)$ & $(0.023)$ & $(0.023)$ & $(0.023)$ & $(0.023)$ \\
\hline \multirow[t]{2}{*}{ Age (in days divided by 365) } & & $-0.117 * *$ & -0.145 & -0.047 & 0.107 \\
\hline & & $(0.055)$ & $(0.117)$ & $(0.320)$ & $(0.460)$ \\
\hline \multirow[t]{2}{*}{$\mathrm{Age}^{2}$} & & & 0.014 & -0.124 & \\
\hline & & & $(0.053)$ & $(0.424)$ & \\
\hline \multirow[t]{2}{*}{$\mathrm{Age}^{3}$} & & & & 0.046 & \\
\hline & & & & $(0.139)$ & \\
\hline \multirow[t]{2}{*}{ Interaction age and negative reciprocity } & & & & & -0.038 \\
\hline & & & & & $(0.070)$ \\
\hline \multirow[t]{2}{*}{ Interaction age and positive reciprocity } & & & & & -0.030 \\
\hline & & & & & $(0.108)$ \\
\hline Observations & 4,520 & 4,520 & 4,520 & 4,520 & 4,520 \\
\hline
\end{tabular}

The measures of negative and positive reciprocity used in the estimations are constructed by taking the average of the three underlying items. Additional control variables in the estimations are: educational levels; sector fixed effects. Standard errors are in parentheses. $* * *<0.01, * *<0.05, *<0.10$. 
Table A2

Separate negative reciprocity components, treatment and job motivation:

\begin{tabular}{|c|c|c|c|}
\hline Dependent variable: Job motivation & (1) & $(2)$ & (3) \\
\hline \multirow[t]{2}{*}{ Interaction treatment and negative reciprocity component } & $-0.084^{* * *}$ & $-0.039^{*}$ & $-0.072^{* * *}$ \\
\hline & $(0.032)$ & $(0.024)$ & $(0.023)$ \\
\hline \multirow[t]{2}{*}{ Negative reciprocity component 2} & -0.026 & & \\
\hline & $(0.023)$ & & \\
\hline \multirow[t]{2}{*}{ Negative reciprocity component 3} & & $-0.163^{* * *}$ & \\
\hline & & $(0.021)$ & \\
\hline \multirow[t]{2}{*}{ Negative reciprocity component 5} & & & $-0.093^{* * *}$ \\
\hline & & & $(0.019)$ \\
\hline \multirow[t]{2}{*}{ Interaction treatment and positive reciprocity } & -0.036 & -0.053 & -0.034 \\
\hline & $(0.064)$ & $(0.064)$ & $(0.064)$ \\
\hline \multirow[t]{2}{*}{ Positive reciprocity } & -0.014 & 0.015 & -0.003 \\
\hline & $(0.048)$ & $(0.047)$ & $(0.048)$ \\
\hline \multirow[t]{2}{*}{ Treatment dummy } & 0.258 & 0.182 & 0.206 \\
\hline & $(0.275)$ & $(0.269)$ & $(0.271)$ \\
\hline \multirow[t]{2}{*}{ Number of years contributed to the pension fund } & -0.004 & -0.004 & -0.004 \\
\hline & $(0.003)$ & $(0.003)$ & $(0.003)$ \\
\hline \multirow[t]{2}{*}{ Log yearly wage } & $0.234^{* * *}$ & $0.189^{* *}$ & $0.207^{* *}$ \\
\hline & $(0.086)$ & $(0.086)$ & $(0.086)$ \\
\hline \multirow[t]{2}{*}{ Log size of organization } & 0.005 & 0.005 & 0.004 \\
\hline & $(0.015)$ & $(0.015)$ & $(0.015)$ \\
\hline \multirow[t]{2}{*}{ Marital status } & 0.085 & $0.104^{*}$ & $0.098^{*}$ \\
\hline & $(0.059)$ & $(0.059)$ & $(0.059)$ \\
\hline \multirow[t]{2}{*}{ Bad health } & $-0.413^{* * *}$ & $-0.405^{* * *}$ & $-0.409^{* * *}$ \\
\hline & $(0.023)$ & $(0.023)$ & $(0.023)$ \\
\hline \multirow[t]{2}{*}{ Age (in days divided by 365 ) } & $-0.116^{* *}$ & $-0.120^{* *}$ & $-0.124^{* *}$ \\
\hline & $(0.056)$ & $(0.056)$ & $(0.056)$ \\
\hline \multirow[t]{2}{*}{ Constant } & $2.191^{* *}$ & $2.885^{* * *}$ & $2.599 * * *$ \\
\hline & $(0.996)$ & $(0.993)$ & $(0.998)$ \\
\hline Observations & 4,539 & 4,533 & 4,526 \\
\hline R-squared & 0.090 & 0.102 & 0.095 \\
\hline
\end{tabular}

OLS estimates. Column 1 shows the results for the statement 'If I suffer a serious wrong, I will take revenge as soon as possible, no matter what the costs', Column 2 for 'If somebody puts me in a difficult position, I will do the same to him/her' and Column 3 for 'If somebody offends me, I will offend him/her back'. Additional control variables in the estimations are: educational levels; sector fixed effects. Standard errors are in parentheses. $* * *<0.01, * *<0.05, *<0.10$. 
Table A3

Negative reciprocity, treatment and mental health

\begin{tabular}{lc}
\hline \hline & $(\mathbf{1})$ \\
VARIABLES & Depressed \\
\hline Interaction treatment and negative reciprocity & $0.022^{* * *}$ \\
& $(0.008)$ \\
Interaction treatment and positive reciprocity & 0.009 \\
& $(0.012)$ \\
Negative reciprocity & -0.009 \\
& $(0.006)$ \\
Positive reciprocity & $0.016^{*}$ \\
& $(0.009)$ \\
Treatment dummy & -0.066 \\
Number of years contributed to the pension fund & $(0.051)$ \\
& 0.001 \\
Log yearly wage & $(0.000)$ \\
& -0.008 \\
Log size of organization & $(0.016)$ \\
Marital status & 0.001 \\
Bad health & $(0.003)$ \\
Age (in days divided by 365) & $-0.044^{* * *}$ \\
Constant & $(0.011)$ \\
& $0.068^{* * *}$ \\
& $(0.004)$ \\
& 0.012 \\
& $(0.010)$ \\
& -0.063 \\
& $(0.172)$ \\
& 4,431 \\
& 0.076 \\
\hline
\end{tabular}

OLS estimates. The dependent variable is based on the CES-D8 indicator of depression which is derived from the Center for Epidemiologic Studies Depression Scale The CES-D8 consists of eight items, six of which are negatively phrased statements that reflect the presence of depressive symptoms, and two positively phrased statements that reflect the absence of depressive symptoms. To create the variable used in our analyses, we first dichotomized (yes/no) responses and reversed the coding of positively phrased items to achieve a count variable from 0 to 8 , with higher values suggesting worsening depressive symptoms. In the next step, we constructed a dummy variable indicating whether workers are depressed. Following De Grip et al. (2012) we used the suggested score of 4 and above to indicate probable clinical depression. Educational levels are included as control variables. Standard errors are in parentheses. $* * *<0.01, * *<0.05, *<0.10$. 
Table A4

Treatment effect on job motivation: Workers with career breaks

\begin{tabular}{|c|c|c|}
\hline & (1) & $(2)$ \\
\hline Dependent variable: Job motivation & 1949 & 1949 and 1950 \\
\hline \multirow[t]{2}{*}{ Interaction treatment 1949 and negative reciprocity } & $-0.228^{* *}$ & $-0.215^{*}$ \\
\hline & $(0.112)$ & $(0.113)$ \\
\hline \multirow[t]{2}{*}{ Interaction treatment 1949 and positive reciprocity } & 0.043 & 0.040 \\
\hline & $(0.151)$ & $(0.153)$ \\
\hline \multirow[t]{2}{*}{ Interaction treatment 1950 and negative reciprocity } & & $-0.122^{* * *}$ \\
\hline & & $(0.042)$ \\
\hline \multirow[t]{2}{*}{ Interaction treatment 1950 and positive reciprocity } & & -0.022 \\
\hline & & $(0.064)$ \\
\hline \multirow[t]{2}{*}{ Negative reciprocity } & $-0.082^{* * *}$ & $-0.094 * * *$ \\
\hline & $(0.031)$ & $(0.031)$ \\
\hline \multirow[t]{2}{*}{ Positive reciprocity } & -0.005 & -0.001 \\
\hline & $(0.047)$ & $(0.048)$ \\
\hline \multirow[t]{2}{*}{ Treatment dummy 1949} & 0.550 & 0.480 \\
\hline & $(0.656)$ & $(0.663)$ \\
\hline \multirow[t]{2}{*}{ Treatment dummy 1950} & & 0.292 \\
\hline & & $(0.277)$ \\
\hline \multirow[t]{2}{*}{ Number of years contributed to the pension fund } & -0.002 & $-0.004^{*}$ \\
\hline & $(0.004)$ & $(0.002)$ \\
\hline \multirow[t]{2}{*}{ Log yearly wage } & $0.277^{* *}$ & $0.176^{* *}$ \\
\hline & $(0.118)$ & $(0.083)$ \\
\hline \multirow[t]{2}{*}{ Log size of organization } & -0.028 & 0.001 \\
\hline & $(0.020)$ & $(0.014)$ \\
\hline \multirow[t]{2}{*}{ Marital status } & 0.042 & $0.117^{* *}$ \\
\hline & $(0.084)$ & $(0.057)$ \\
\hline \multirow[t]{2}{*}{ Bad health } & $-0.393^{* * *}$ & $-0.407 * * *$ \\
\hline & $(0.031)$ & $(0.022)$ \\
\hline \multirow[t]{2}{*}{ Age (in days divided by 365 ) } & -0.065 & $-0.100^{*}$ \\
\hline & $(0.078)$ & $(0.055)$ \\
\hline \multirow[t]{2}{*}{ Constant } & 2.025 & $2.714^{* * *}$ \\
\hline & $(1.316)$ & $(0.918)$ \\
\hline Observations & 2,305 & 4,720 \\
\hline R-squared & 0.090 & 0.099 \\
\hline
\end{tabular}

OLS estimates. Column 1 presents estimation results for workers born in 1949. The treatment dummy equals one for workers who are not entitled to the old pension rights since they did not work in the public sector continuously since April 1997, and zero for workers who remain entitled to the old pension rights. Column 2 contains estimation results for the 1949 cohort, as well as the 1950 cohort. The model includes two treatment dummy variables. The first treatment dummy equals one for workers born in 1949 and who are not entitled to the old pension rights and zero otherwise. The second treatment dummy equals one if workers were born in 1950 and zero for those born in 1949. Additional control variables in estimations are: educational levels; sector fixed effects. Standard errors are in parentheses. $* * *<0.01, * *<0.05, *<$ 0.10 
Figure A1 Distribution average negative reciprocity: Treatment

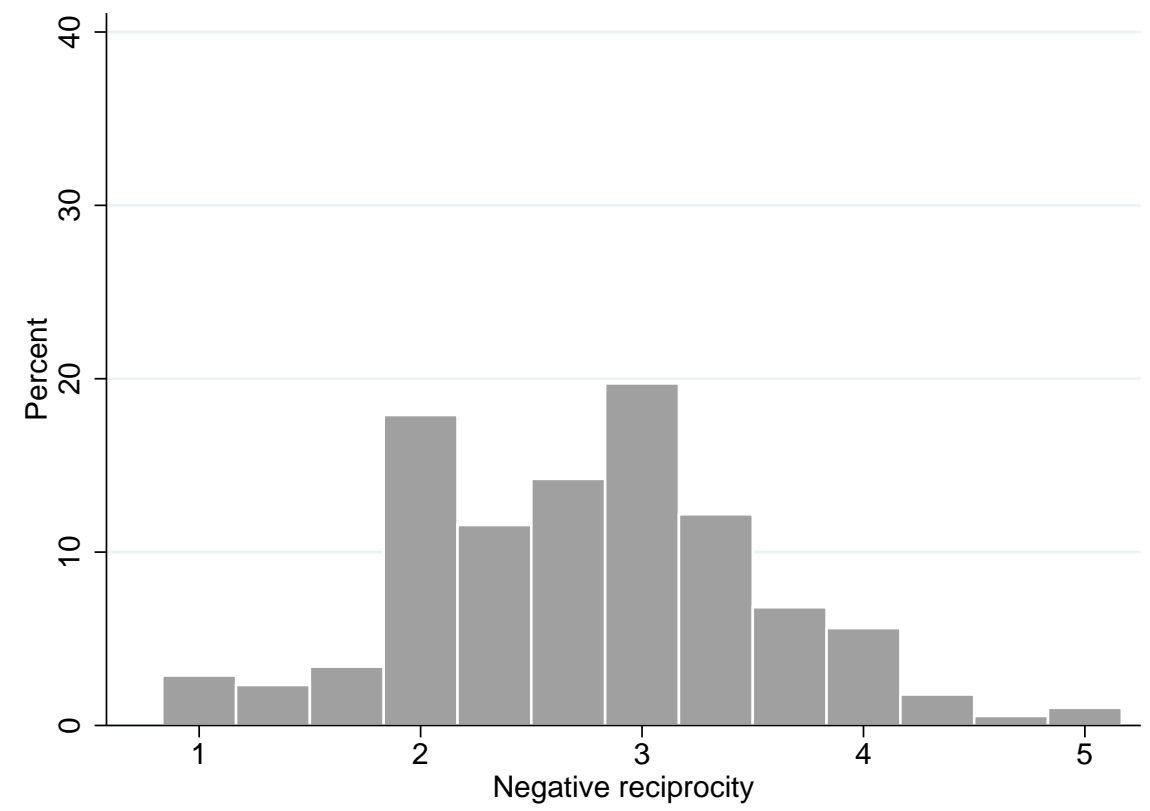

Figure A2 Distribution average negative reciprocity: Control

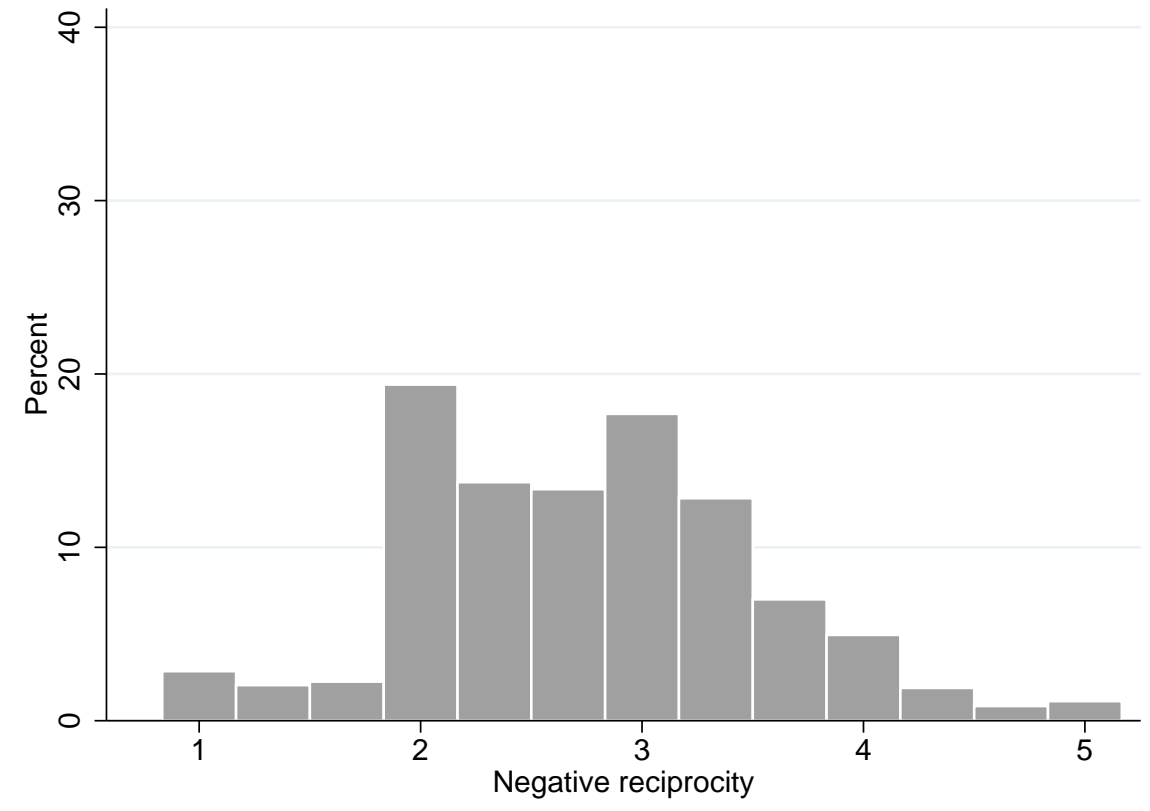


Figure A3 Distribution average positive reciprocity: Treatment

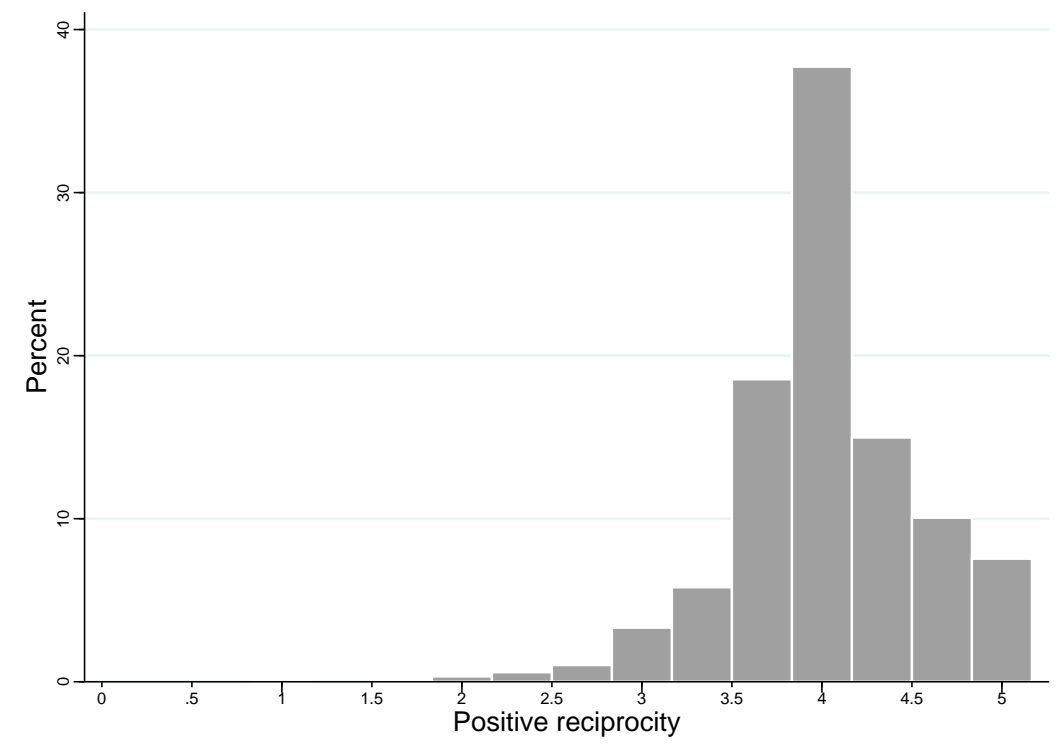

Figure A4 Distribution average positive reciprocity: Control

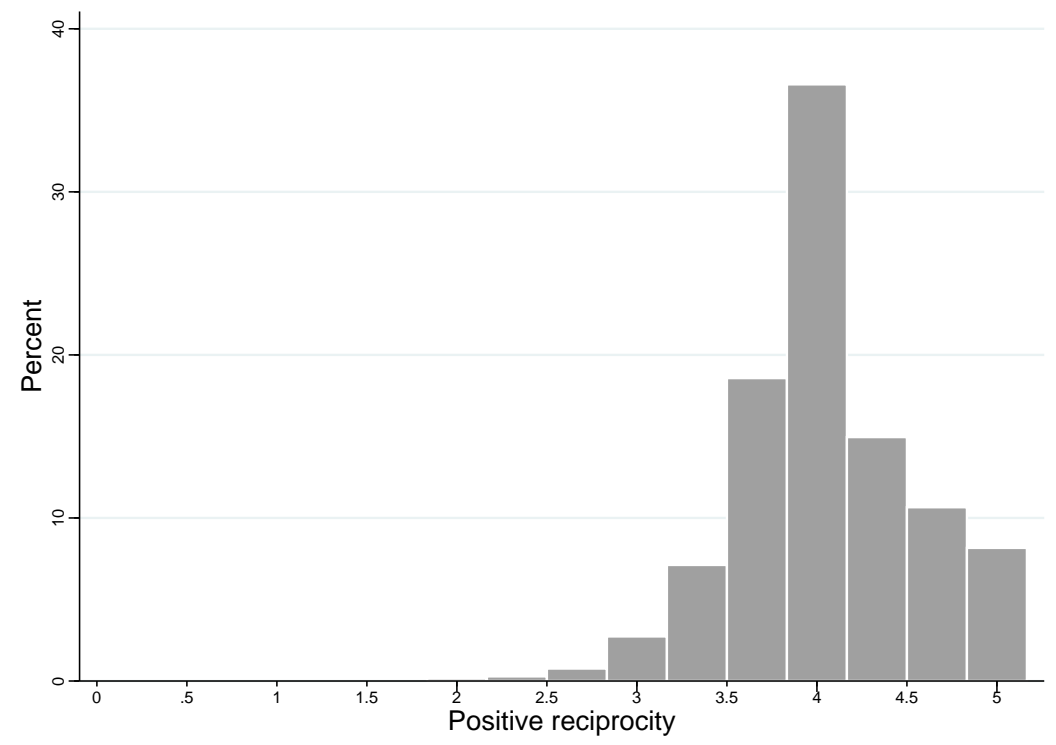

